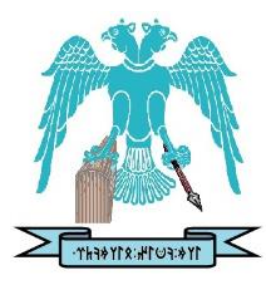

JOURNAL OF ENERGY SYSTEMS

$2019,3(4)$

\title{
Developing an energy informatics application for hybrid green buildings
}

\author{
Hacı Veli Kalmış ${ }^{(D)}$ \\ Kahramanmaraş Sütçüimam University, Department of Informatics, Kahramanmaraş, Turkey, \\ haveka046@gmail.com \\ Ahmet Serdar Yilmaz ${ }^{(D)}$ \\ Kahramanmaraş Sütçüimam University, Electrical and Electronic Engineering Department, \\ Kahramanmaraş, Turkey, asyilmaz@ksu.edu.tr
}

Mehmet Tekerek

Kahramanmaraş Sütçüimam University, Computer Education and Instructional Technology Department, Kahramanmaraş, Turkey, tekerek@ksu.edu.tr

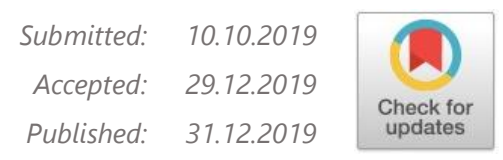

\begin{abstract}
Renewable energy sources are important in the green building for energy saving. The use of renewable energy sources needs energy management in hbyrid green buildings. By using an energy management system, the energy costs of hyrid green buildings can be systematically and regularly controlled. In other words, it provides each consumer to produce their own energy in their own building, and reduce the dependence to the central power grid. Besides, the change of electricity pricing according to hours can be seen as another parameter. The aim of this study is to develop an energy informatics application for energy management in green buildings. Resource management scenarious have been created according to regional atmospherical conditions. These scenarious were monitored via an energy source management interface. In this study, a software which have a visual interface was developed. This software conducts an energy management system for a hybrid green building which has three kinds of energy resource like utility, solar arrays and energy storage system. This software proposes an resource management system between these three types of resources.Proposed system depends on some scenarious which are interchangable according to external parameters such as; variability of the price of energy received from electric grid, seasonal factors, fullness level of the batteries were designed. In the scenarios of the electric loads, making them continuous and as cheap as possible were taken into consideration. With the developed software, it is aimed to monitor energy consumption of each scenario. Thus, an arrangement using cheap, continuous and environmentally friendly resources as possible as will be provided.
\end{abstract}

Keywords: Building energy simulation, Energy informatics, Green building, Renewable energy sources Cite this paper as: $\quad$ hybrid green buildings. Journal of Energy Systems 2019; 3(4): 189-205, DOI: $10.30521 /$ jes. 663040

(C) 2019 Published by peer-reviewed open access scientific journal, JES at DergiPark (https://dergipark.org.tr/en/pub/jes) 


\section{INTRODUCTION}

Energy is defined as one of the basic needs of human being to continue daily life and the ability to do tasks [1]. For this reason; humans have lived near energy resources, founded countries and even fought for energy. Moreover, one of the leading factors for social development is energy use. However, fast consumption of energy resources, unconscious use of non-renewable resources and the environmental pollution prompt developed societies to make plans about alternative resources. In these plans, while keeping the balance between energy-economy-ecology, it is encouraged to use renewable resources, which take variety of resources and jeopolitical realities into consideration [2].

Alternative energy resources can be summarized as: Solar energy is a clean energy resource produced directly by sunshine. The first studies on conversion of solar energy into electrical energy were photovoltaic batteries, which were invented by French physicist Alexandre Edmond Becquerel in 1839 [3]. The first detailed study on photovoltaic was done by Albert Einstein in 1905 and won Nobel Physics Prize in 1921. The studies related to silicone cells were done by Daryl Chapin, Calvin Fuller ve Gerald Pearson in 1954 [4]. The first technical application took its place in satellite technology with "Vanguard 1 " satellite in 1958. Space sector became pioneer in the development of photovoltaic cells between 1960-1970. These developments have continued gradually since the petrol crisis in 1973 [5].

PV cells are systems that convert solar energy directly into electrical energy. As the technology develops, PV panels are used in watches, calculators, streetlights and even in traffic signs and boards effectively. PV panels are also used in solar power plants. Since 1981, speacial roof panel systems have been produced for the roof of buildings and then PV panels are used as roof covering. The studies conducted on the effects of sunlight on panel had positive results. Practical studies have increased since 1992. Today the studies about economical PV panel production have increased and thus, it resulted in creating new market places by the increase of industrial usage [6]. Wind energy is produced by turning wind's kinetic energy into electrical energy. Turning electrical energy into wind energy is firstly produced in Denmark. In 1897, a Danish meteorologist Paul La Cour, set up first 89 Watt wind power station to generate electricity [7]. According to Global Wind Energy Council's (GWEC) report in 2017, the use of wind energy consists of $4 \%$ of total energy resources in the world [8].

Geothermal energy is the conversion of the potential of heat with high temperature and pressure stored underground into electrical energy. Electricity generated from geothermal energy was first applied in Larderello, Italy in 1913. This application consists of the system based on dry steam generation from wells [9]. In the world, the rate of electricity production from geothermal energy is about $0.04 \%$. According to International Energy Agency's (IEA) predictions, geothermal energy will account for 3,5\% of total electricity production in 2050 [10]. Hydroelectric energy is the transformation of the energy of flowing water into electrical energy. Hydroelectric power plant was first established in 1890 and started to generate energy [11]. According to 2011 data, 14\% of the total energy generated in the world is generated from hydroelectric power plants [12]. In addition to these, energy sources such as Biomass Energy, Hydrogen Energy and Wave energy can be considered as alternative energy sources.

Considering the advantages and disadvantages of renewable energy sources, renewable energy sources can be re-used once they have been used by returning to previous state naturally. This specification allows the use of renewable energy almost unlimitedly. Renewable energy can be considered as a free energy resource with some exceptions and it is a kind of a clean energy type. Therefore, renewable energy production stages exhibit an environment-friendly, non-polluting structure. It has a great importance to reduce emissions in the fight against greenhouse effect. A significant part of the technology necessary to obtain energy from renewable resources is available in today's world [13]. 
On the other hand, some alternative sources of energy, such as sun and wind, are not available 24 hours a day. Alternative energy sources are stored for later use. The process of storing renewable energy sources is not only expensive but also difficult [14]. As a result of the imbalances in energy use, it is urgent to use energy efficiently and economically. Energy efficiency encompasses overall activity work in the field of both production and transmission and distribution of energy and consumption.

Another issue with energy is to generation more energy and to do more work with this energy with less cost and less primary resources. Therefore, various studies are carried out, measures are developed and strategies are developed in order to make the same amount of work with less energy consumption [15]. Sustainability, quality and low cost of energy are required where energy needs are high. Considering the additional financial burden on uncontrolled energy consumption, the importance of disciplines for the efficient consumption of energy clearly indicates the need for energy management [16].

In order to meet the energy needs efficiently, the use of alternative energy sources is one of the issues considered today. In addition to the structures in which direct mains supply is used by using alternative energy sources, there are also structures in which the energy is used at the place it is generated and the surplus is directed to the grid. Hybrid green buildings that both take their energy from the grid and generate and store their own energy can be given as examples. The use of energy at the place where it is generated storage of energy or routing of the energy to the grid emerges as an energy management problem that needs to be solved.

In accordance with the developing technology, information technologies in energy studies and energy management have gained importance. In the report published by the United Nations in 1998, the problems related to fossil fuel in the world were emphasized. In addition to these problems, when the population and economy parameters are added, it is necessary to do some studies for future generations. United Nations has recommended studying intensively on sustainable society and efficient use of energy resources In its report. As a result of this situation and the data from the studies, the concept of Energy Informatics was emerged from the idea of creating information systems and generating effective solutions for energy together with information technologies [17]. Energy Informatics is a discipline related to information flow in information and energy systems, especially in the use of calculation methods to increase energy demand and the efficiency of supply systems [19]. Energy informatics aims to increase the efficiency of the systems that meet the energy needs and focuses on the analysis, design and implementation of these systems. It requires the collection and analysis of energy data to support the efficient use of energy distribution and consumption networks [18].

According to another definition, "supply and demand" is defined as an environmentally sensitive, energy-oriented research agenda of enterprises that can, analyze, design and implement an information system to improve the energy process [17]. Finally, energy informatics focuses on saving, efficiency, sustainability, environmental sustainability and utilization of the energy. Information and communication technologies are currently used in the sustainable energy sectors such as intelligent grid, renewable energy, electric vehicles and storage. [18].

There are examples of energy informatics applications in many countries of the world. For example, the Dutch rail transport network has been optimized with a software from IBM to save up huge saving. In the San Francisco city of America, the parking problem of the vehicles was solved with the help of sensors and the vehicles are parked as quickly as possible and thus the vehicles are saved in fuel.In France, the bicycle-sharing project with a special software has helped to reduce the number of vehicles in transit. The traffic system with a special card filling system on highways helped to regulate traffic problem in Singapore [17]. The first step of energy management is to monitor energy. Energy Monitoring Systems (EIS) are necessary for buildings and industrial facilities. It may be possible to provide efficiency through an appropriately configured EIS [20]. 
These studies should be compatible with the framework of energy informatics. The Energy Informatics framework recommends defining the main components (flow networks, sensor networks, sensitive objects and information systems) specified in Fig. 1.

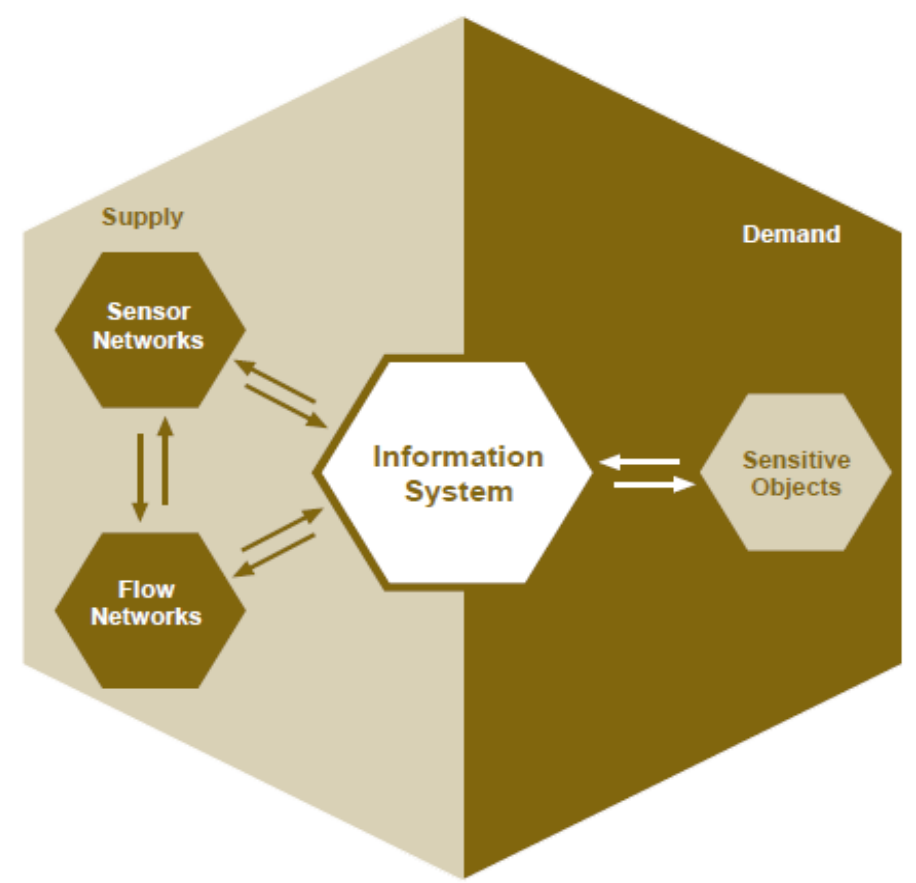

Figure 1. Main components of the Energy Informatics framework [21]

The purpose of the energy informatics framework is to provide a framework for planning as it is recommended to identify the main components (flow networks, sensor networks, sensitized objects, and information systems) that must be taken into account in an energy management planning application. With the emphasis on the use of sensor networks for collecting energy data sets, the energy informatics framework also provides data streams to control and analyze performance over multiple time intervals [21].

As a result, global warming, thirst, environmental pollution and the rapid depletion of natural resources have led to the development of environment friendly buildings in the construction sectorThis situation has created a new sector in the construction sector as green buildings, which are more valuable, respectful to nature, ecological, comfortable and reduce energy consumption [22]. Green buildings, which are sustainable, ecological, environment friendly etc., are the buildings that are compatible with nature starting from land selection. In addition, they are designed in a holistic way, based on social and environmental responsibility, suitable for climate data and conditions specific to the place, sustained as much as needed, directed towards renewable energy sources, nature and waste. They are defined as sensitive and sustainable structures that use non-producing materials [23]. Green buildings are the designs that provide energy needs mostly from renewable sources, are environmentally friendly and aim to use energy at the lowest cost.

In this study, we focused on the energy source management of a green building based on the problem of using, storing the energy where it was produced or directing it to the grid. Alternative energy sources are not continuous. For this reason, it is aimed to develop an energy informatics application for the green building application, which is energized as hybrid in the study. Resource Management Scenarios (RMS) have been created according to parameters such as variability of cost of energy taken from the network, seasonal factors, battery occupancy rate. In resource management scenarios, it is essential that electricity charges are always energized and that it is cheap and renewable. An energy informatics software has been developed in order to monitor the implementation of the created resource management scenarios and to evaluate the results. 
When the necessary conditions are met with Hybrid Green Building Energy Supply management software, it is possible to decide which scenario will be active and it is possible to monitor the energy consumption. The interface is real-time and is based on the battery's charge values. The software is accessible via the Internet. Thus, it is aimed to reach a hybrid green house energy management using cheap, continuous and environmentfriendly resources as much as possible.

\section{MATERIAL AND METHOD}

Developing an energy informatics application for hybrid green buildings is a software development application. Software development is the entire set of activities that includes processes such as analysis, design, coding, testing to reveal the software product that is supposed to meet one or more needs in operational terms.

\subsection{Resource Management Scenarios}

In practice, energy resource management scenarios have been formed by considering regional conditions. The tariff parameter used in the creation of the scenarios was made on the basis of supply and demand. 3-time tariff is shown in Table-1, depending on supply and demand.

Table 1. Smart tariff (3-time tariff) depending on supply and demand

\begin{tabular}{llll} 
Tariff & Time & Usage & Energy Price \\
\hline T1 & $06: 00-17: 00$ & Normal & Normal \\
T2 & $17: 00-22: 00$ & More & Expensive \\
T3 & $22: 00-06: 00$ & Lass & Cheap \\
\hline
\end{tabular}

As data pertaining to day and night status about the annual sunrise-sunset times for Kahramanmaras do not change according to years, the information in the list can be used for backwards and forwards each year [24].

In the resource management scenarios, 10 different situations are planned by taking into consideration: the time of the day (daylight or night time) and the occupancy rate of the battery. The structure and application interface representing the hybrid green house in the study are shown in Fig. 2.

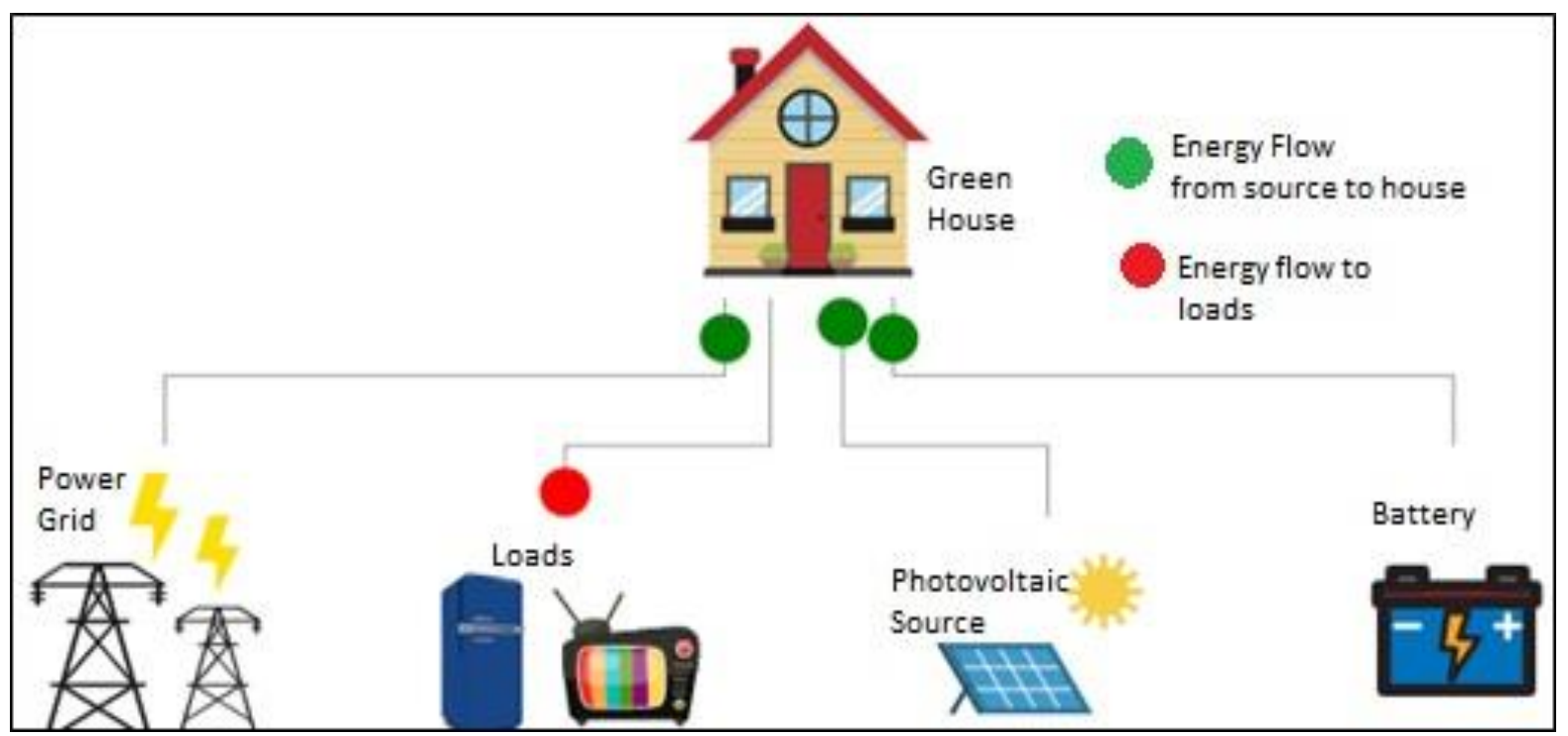

Figure 2. Green Building Energy Cycle 
When the occupancy and clearance rates of the batteries are taken into consideration, the voltage values of the standard batteries used in vehicles change between $6 \mathrm{~V}-120 \mathrm{~V}$ [25]. In this study, the battery is considered as full, half full or empty according to the occupancy rates of a $24 \mathrm{~V}$ battery.

Table 2 shows the resource management scenarios created for the hybrid green house consisting of main connection, photovoltaic solar panels and battery by using the above mentioned parameters.

Table 2 Charge, discharge and energizing conditions according to scenarios

\begin{tabular}{lllll}
\hline SMS & Grid & PV & Battery & Load \\
\hline 1 & On & Off & Charge & On \\
2 & On & On & Charge & On \\
3 & On & On & Discharge & On \\
4 & Off & Off & Discharge & On \\
5 & Off & On & Charge & On \\
6 & Off & On & Discharge & On \\
7 & To Grid & Off & Discharge & On \\
8 & To Grid & On & Charge & On \\
9 & To Grid & On & Discharge & On \\
10 & On & Off & Discharge & On \\
\hline
\end{tabular}

When Table 2 is examined, in the scenario 1, the main power supply is the grid and no energy is received from the photovoltaic panels (PV OFF). In addition, batteries are charged with energy demanded from the grid. This scenario is active at sunset in other words at night. It is also more useful when price of electricity is cheaper. In the scenario 2, the main power supply is photovoltaic panels and the electricity grid (Grid On, PV On). Batteries are also charging in this scenario. This scenario is active at sunrise. In the scenario 3, the main power supply is the photovoltaic panels with the electricity grid (Grid On, PV On). In addition, energy is absorbed from the batteries, namely the batteries are discharged. This scenario is active during daytime. It is expected that this scenario will work towards the winter months and sunset when the photovoltaic panels cannot be sufficiently powered. In the scenario 4, energy is not absorbed from both the electricity grid and the panels (Grid Off, PV Off), which means that the energy is provided only from the batteries when they are fully charged. It is a useful scenario where the unit price of electricity is the most expensive

especially in the evening. When battery capacity is considered, it should not be expected to continue for a long time. In the scenario 5, the main power supply is photovoltaic panels (PV on) and no energy is taken from the electricity grid (Grid Off). The batteries are also being charged in this scenario. It is expected that this scenario will work during the daytime in the summer. All energy consumption is supplied by panels. It is planned for time periods when local consumption is relatively low, but solar panels produce high levels of energy. In the scenario 6, photovoltaic panels (PV On) and batteries are used as the main power supply. There is no supply from the electricity grid (Grid Off). This scenario is estimated to work especially at sunrise in long days and it is predicted to be active for a short time. The scenario 7 is actually a rare scenario. It is considered in view of the time periods when energy consumption is low and panels do not generate energy. In terms of battery capacities, it is a very shortlived scenario which is not expected to happen or will take place for a very short time. It is likely to happen when the energy is expensive in the time interval between the evening hours and the dawn. The scenario 8 is also a rare scenario. In this scenario, where solar panels are the only source of energy production, both batteries are charged and the excess energy is supplied to the grid. This scenario is likely to occur during the daytime in summer and may be active in situations where there is almost zero selfconsumption. The scenario 9 is a rare scenario as scenarios 7 and 8 . The main power supplies are batteries and solar panels. This scenario is also likely to occur during the daytime in summer and may be active in situations where there is almost zero self-consumption. This scenario is possible to work for a short time with scenarios 7 and 8 . The scenario 10, in which the batteries and grid are the main power supply is very similar to scenario 1 , and is alternatively added to prevent overcharging of the batteries. While the scenario 1 continues, the batteries are also supplying energy when they are fully charged. This is necessary for the protection of batteries. The requirements for scenario 1 also apply to this scenario. 


\subsection{Energy Source Management Software for Hybrid Green Building}

With the developed software, it aims to monitor the energy consumption in each of the decision-making scenarios. The interface is real-time. It works based on the battery charge values. The software was developed by using the $\mathrm{C}++$ programming language [26], Javascprit [27]. MS Office Access [28] was used as a database. The real-time and date, battery status display, day and tariff display on the interface are shown in Fig.3.

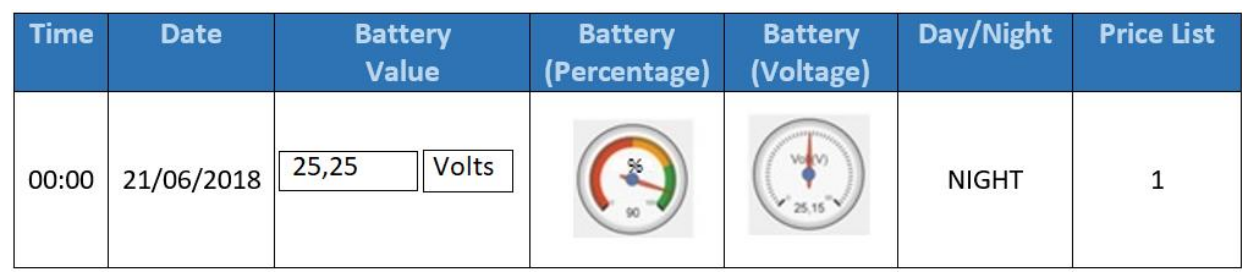

Figure 3. Time-Battery Data Display

Scenario screen showing PV, battery and network status are shown in Fig. 4.

\begin{tabular}{|c|c|c|c|c|}
\hline SCRIPT NO & GRID & PV & BATTERY & LOAD \\
\hline 3 & ON & ON & DISCHARGE & ON \\
\hline \multicolumn{4}{|c}{ Figure 4. Scenario Screen }
\end{tabular}

The battery value is entered manually, and after the system has started, the display of Fig. 5 is activated. When there is a scenario alteration, it shows the scenario time in the first section. The second part records at certain time intervals and the voltage is displayed with time dependent change. In the third section, the screen showing the daily total times in the scenarios of the voltage values is shown in Fig. 5. These data are transferred to excel file through access. The data transferred to the data are evaluated.

\begin{tabular}{|c|c|c|c|c|c|c|c|c|c|c|}
\hline 1 & 2 & 3 & 4 & 5 & 6 & 7 & 8 & 9 & 10 & $\begin{array}{c}\text { Total } \\
\text { Duration }\end{array}$ \\
\hline $00: 00: 00$ & $00: 00: 00$ & $00: 00: 00$ & $00: 00: 00$ & $00: 00: 00$ & $00: 00: 00$ & $00: 00: 00$ & $00: 00: 00$ & $00: 00: 00$ & $00: 00: 00$ & $00: 00: 00$ \\
\hline
\end{tabular}

\begin{tabular}{|c|c|}
\hline $\begin{array}{c}\text { Script } \\
\text { No }\end{array}$ & $\begin{array}{c}\text { Passed } \\
\text { Time }\end{array}$ \\
\hline $\mathbf{5}$ & $\mathbf{0 0 : 0 0 : 0 0}$ \\
\hline
\end{tabular}

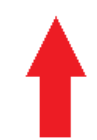

1st PART

\begin{tabular}{|c|c|c|}
\hline Script No & Time & $\begin{array}{c}\text { Battery } \\
\text { (V) }\end{array}$ \\
\hline 3 & $00: 00: 00$ & $\mathbf{2 5 . 3 5}$ \\
\hline 3 & $00: 00: 00$ & $\mathbf{2 5 . 3 5}$ \\
\hline 3 & $00: 00: 00$ & $\mathbf{2 5 . 3 5}$ \\
\hline
\end{tabular}

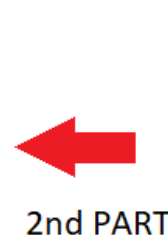

2nd PART

Figure 5. Scenario-Time-Battery Change

\subsubsection{Pseude Code and Flow Diagram}

The pseudo code (Appendix 1) and flow diagram created for implementation of the decision making application for the Hybrid Green Building Energy Source Management Software is as follow (Fig.. 6). 


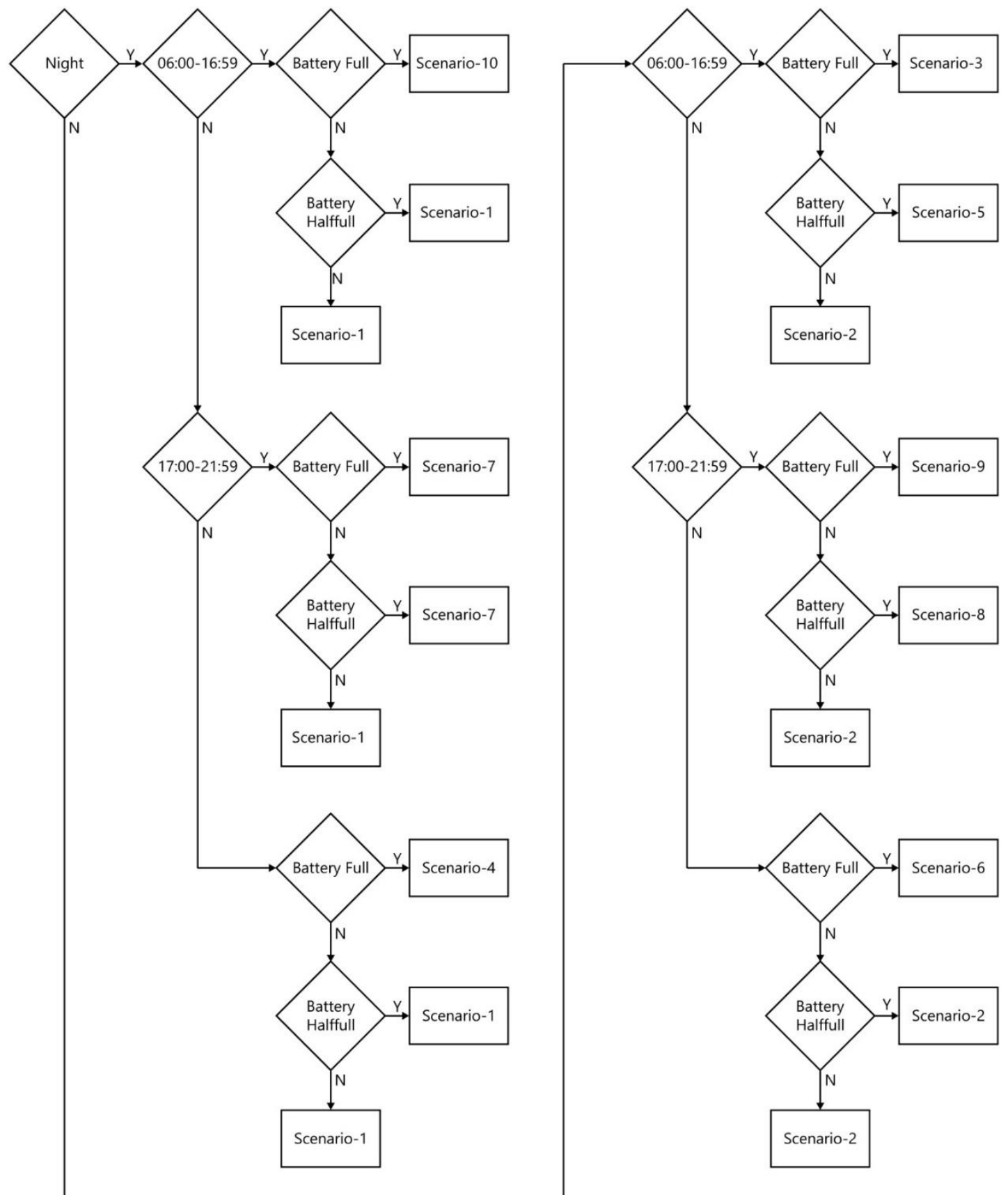

Figure 6. Working algorithm of developed software

\section{RESULTS}

In the energy management application for the hybrid green building, sampling was done for $21^{\text {st }}$ December and $21^{\text {st }}$ June. These samplings cover a full day and were repeated three times, regarding the battery was either empty, half full or full. In this study, the results are given only for the empty and halffull battery conditions on the longest daytime of the year, $21^{\text {st }}$ June and the shortest daytime of the year, $21^{\text {st }}$ December, The results are given in the following figures. According to the data obtained, the variation of the battery voltage and the alteration of the scenarios for 24 hours are shown. According to the data obtained in December when the battery is empty, scenario transition states, voltage variation and scenario alteration graphs of the scenarios for 24 hours are shown in Fig. 7, 8 and 9, respectively. 


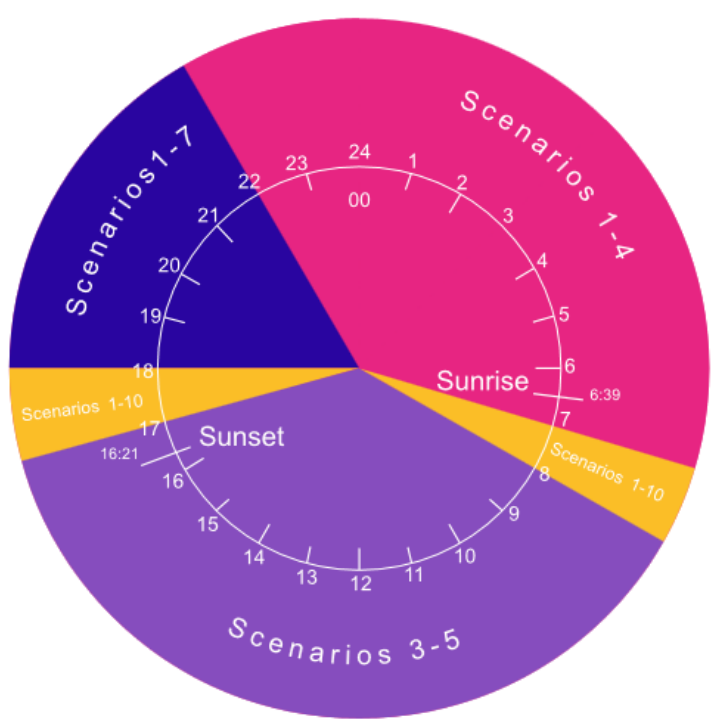

Figure 7. Scenario Transition Status When Battery is Empty in December

From the graph given in Fig. 7, for December 21 and when the battery is empty, after a full day work, there are short-term transitions between the scenarios 1 and 4 at night and it continues until the sunrise.

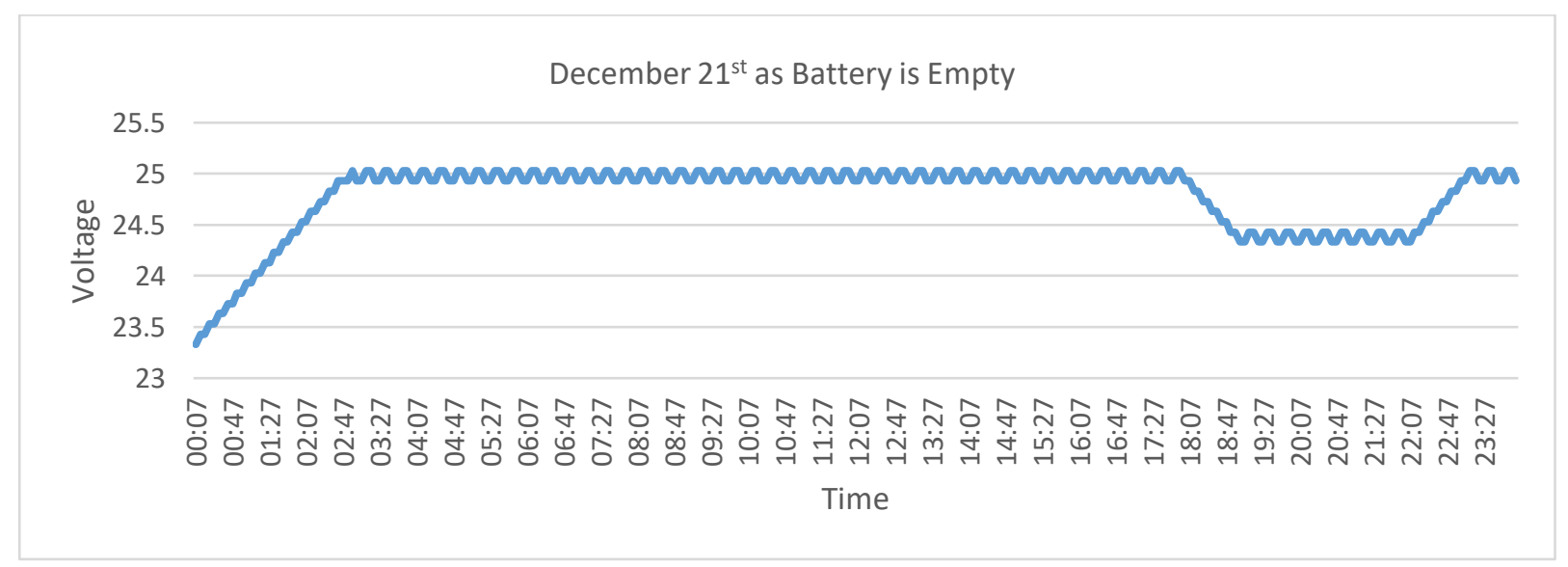

Figure 8. Voltage Variation when the Battery is Empty in December

As it can be seen from the graph of battery voltage variation in Fig. 8, it is observed that the alteration between the scenarios is holding in 5 or 10 minutes time intervals. This is because the battery voltage varies between full and half full.

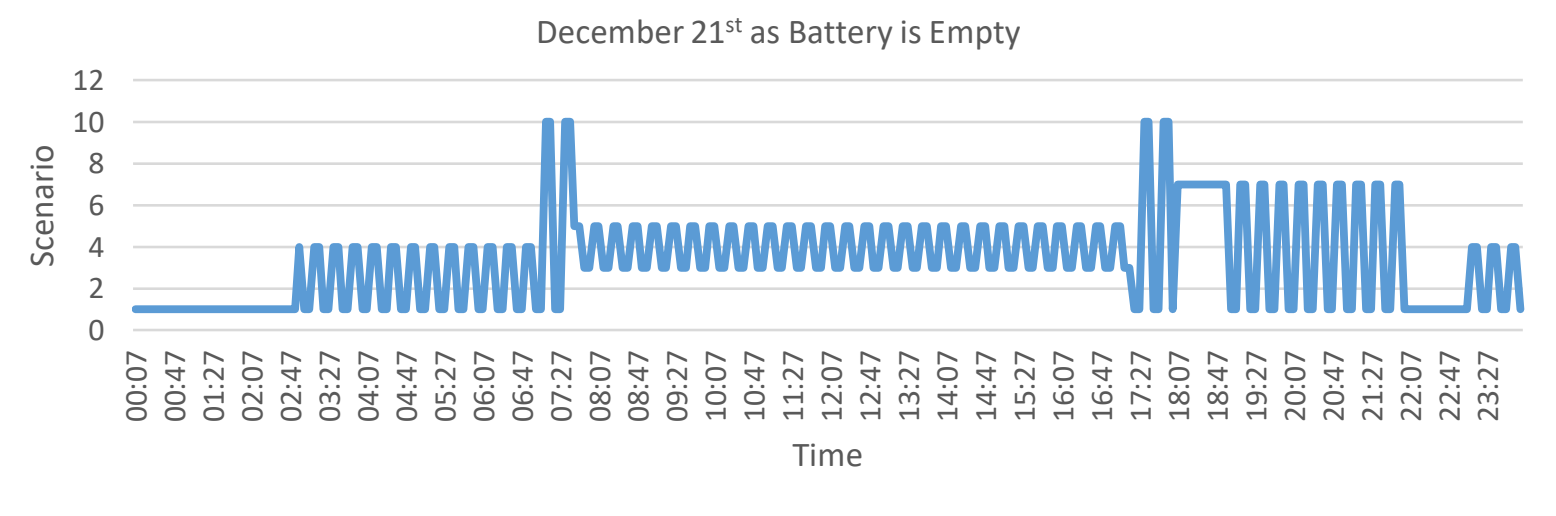

Figure 9. Scenarios When Battery is Empty in December 
As shown in Fig. 9, when the battery was empty at 00:00, the application was activated and the scenario 1 remained active until the battery was fully charged. Afterwards, mutual transition between scenario 1 and 4 was observed.

In the scenario 1, the battery is charged from the electricity grid until the battery is fully charged. When the battery is fully charged, supply from grid is deactivated and there are transitions between the scenario 4 , in which the battery is the main power supply. After the sunrise, transitions were observed for a short time with the scenario 10 instead of the scenario 4 . After the 2 nd tariff, transitions between the scenarios 3 and 5 were observed. The difference of the scenarios 3 and 5 from the scenarios 1 and 10 is that photovoltaic panels are active. The main basis for the passage of the scenario 3 and 5 is that the battery is full and half full. There were transitions between the scenarios 1 and 7 in the evening hours when the energy use was the most intensive and the most expensive. In the scenario 7, the full battery is intended to meet the internal requirement. It is also defined in this scenario that if there is an excess energy in the battery over the internal need, this excess energy is sold to the grid. This situation continues until midnight. In other implementation, the status of half-full battery is discussed for December. In this case, according to the data obtained, scenario transitions, voltage variations and scenario alterations for 24 hours are shown in Fig. 10, 11 and 12, respectively.

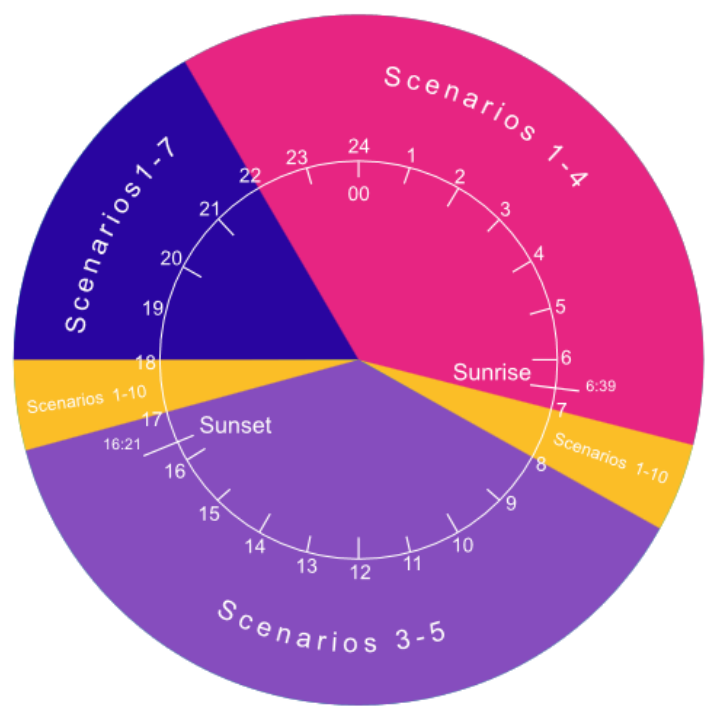

Figure 10. Scenario Transition Status when Battery is half full for December

As it can be seen in Fig. 10, the scenario transitions are similar to Fig. 7, where the battery is empty. Also after midnight, there were transitions between the scenarios 1 and 4 , and during the daytime the scenarios 3 and 5 were realized.

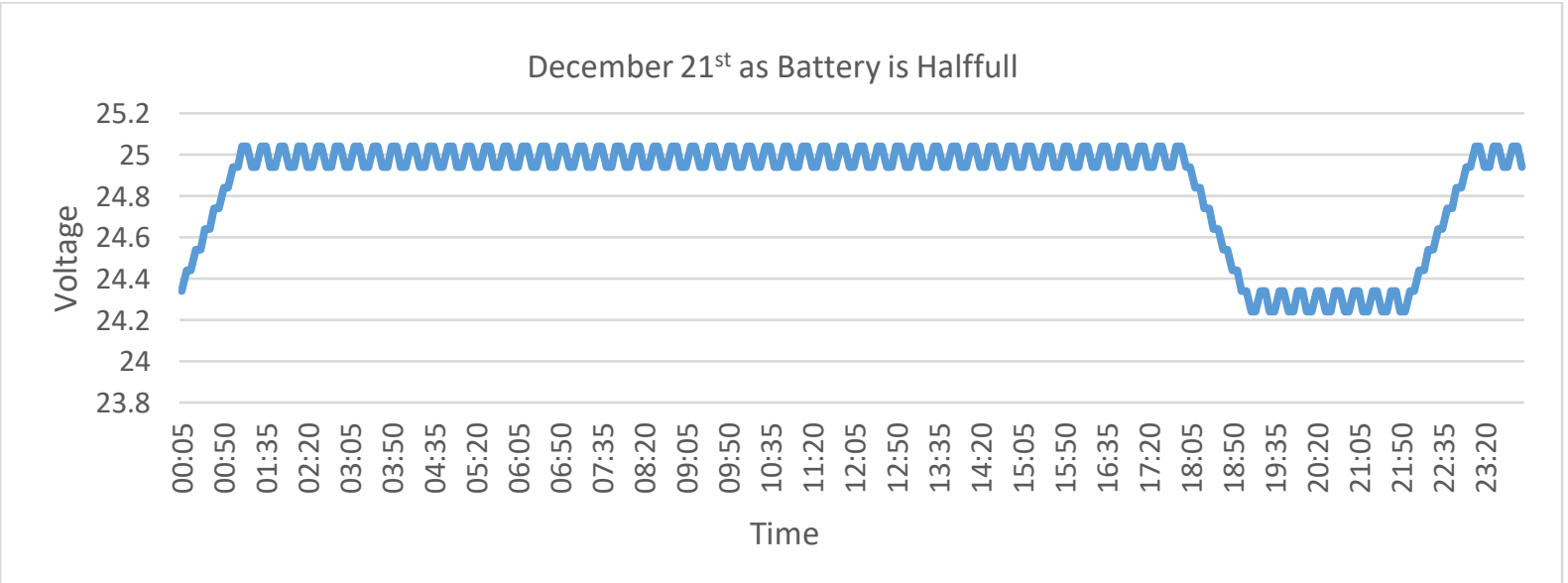

Figure 11. Voltage Variation when the Battery is half full in December 
Fig. 11 shows the voltage variations of the application for 21 December and half-full battery status. A change is observed around the limit voltage of the battery being half full and full. In the developed resource management system, as the battery is one of the main targets to fully charged, it is seen that there is a transition to the scenarios in which the battery is charged as the voltage drops.

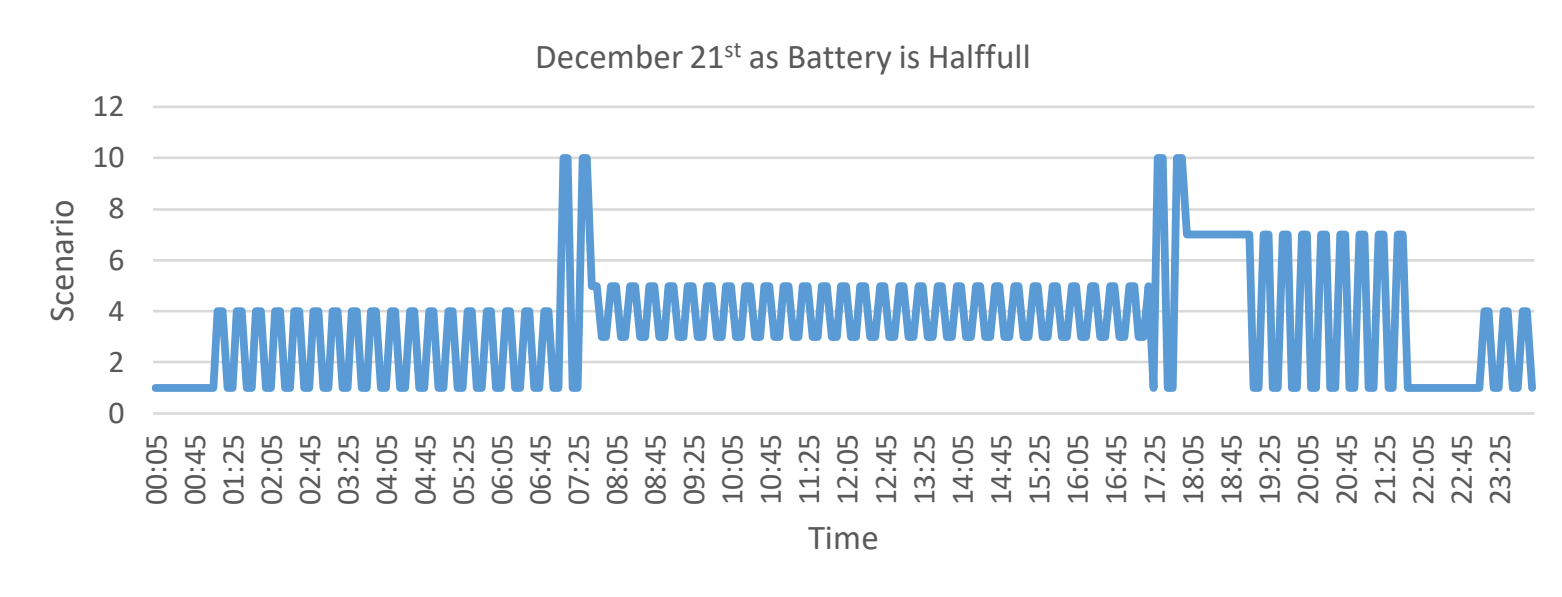

Figure 12. Scenarios When the battery is hal full in December

Scenario alterations in Fig. 12 also support this view. After midnight, when the battery voltage drops to half-full level, it is observed that the scenario 1 , and during the daytime, scenario 3 works alternately with scenarios 4 and 5 .

According to the data obtained in June and when the battery is empty, scenario transition states, voltage variation and scenario alteration graphs for 24 hours are shown in Fig. 13, 14 and 15, respectively.

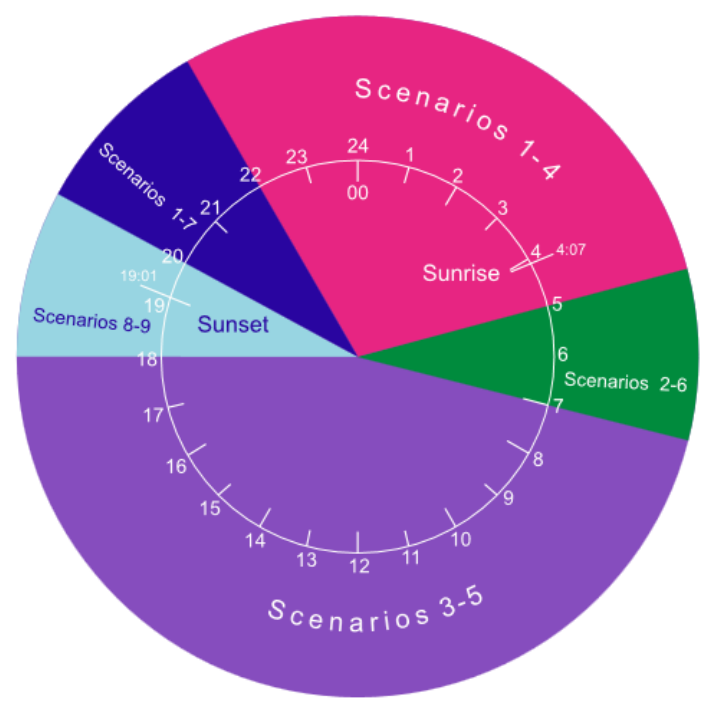

Figure 13. Scenario Transition Status When Battery is Empty in June

As it seen in Fig. 13, in June 21 and when the battery is empty, there are transitions between the scenarios 1 and 4 during the night when the system is running 24 hoursperiod. These transitions continue until the sunrise. 


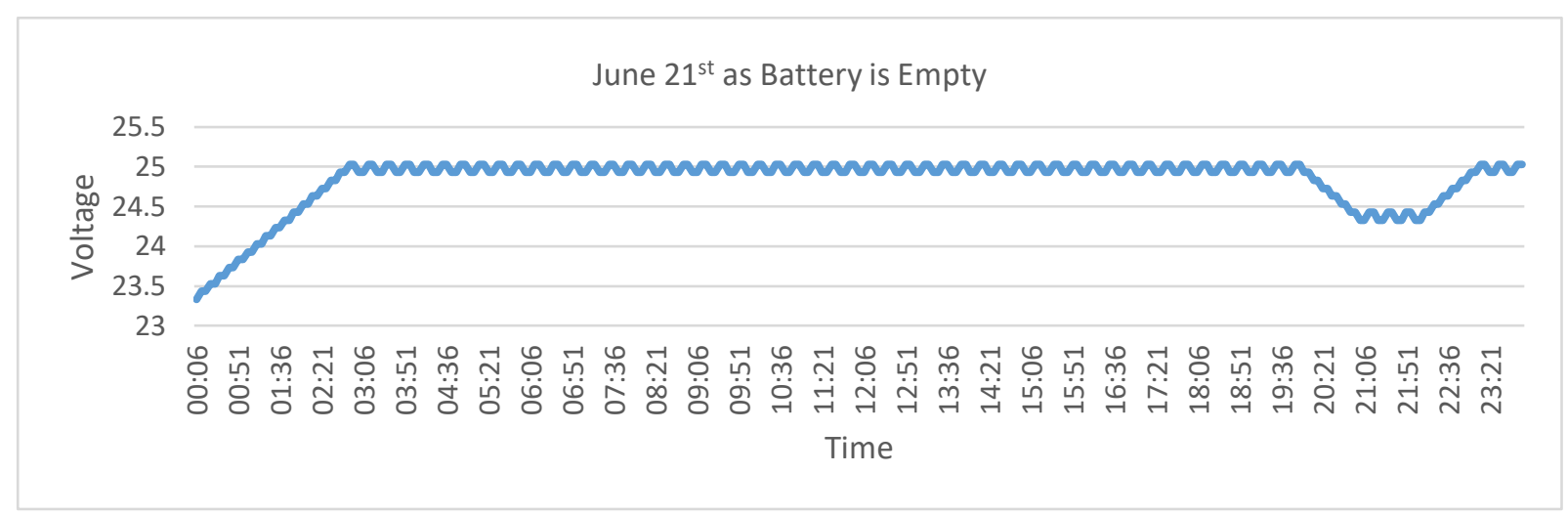

Figure 14. Voltage Change When the Battery is Empty in June

As it seen in Fig. 14, the time changes are in 5 or 10 minutes intervals (bence gereksiz cümle. Grafikte böyle birşey görülmüyor). The reason for this is that the voltage in the battery varies between full and half full.

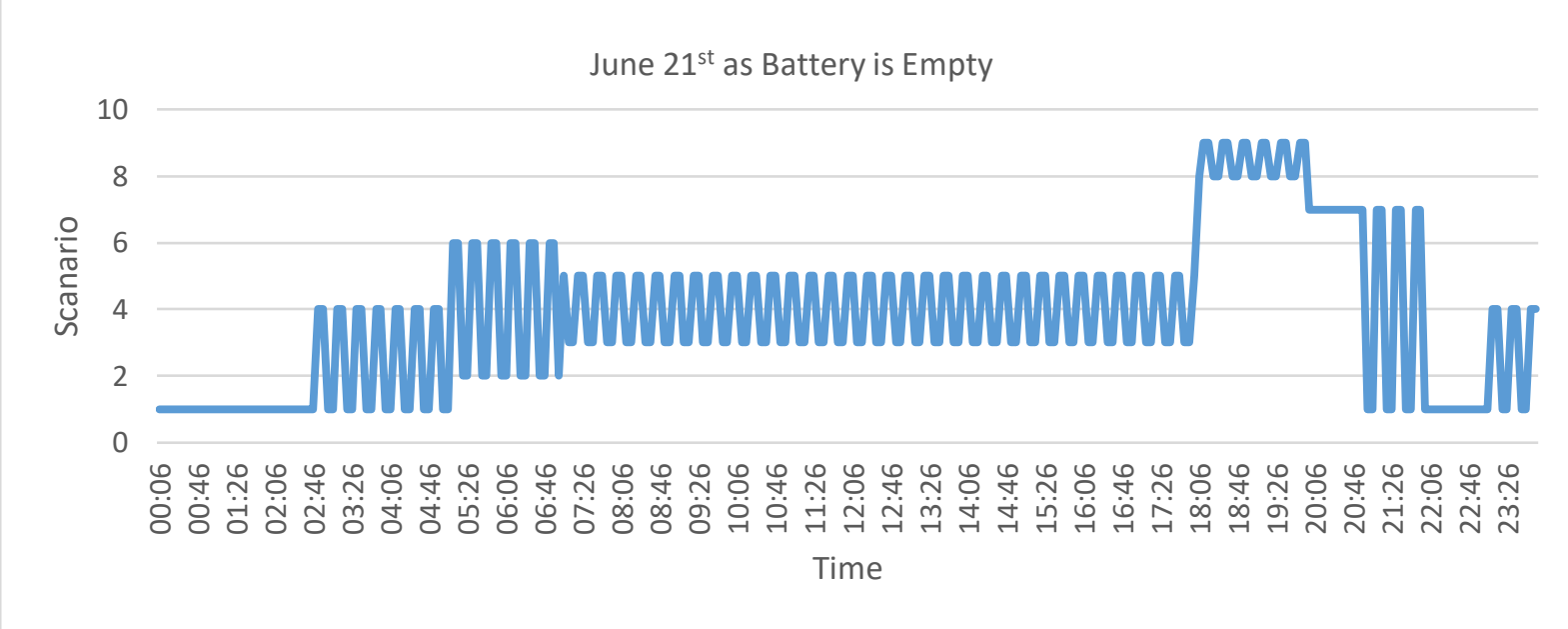

Figure 15. Scenarios When the Battery is Empty in June

As seen in Fig. 15, when the battery was empty at 00:00, the application was activated and the scenario 1 remained active until the battery was fully charged. Mutual transitions were observed between scenarios 1 and 4 until the sunrise. In the scenario 1, the battery is charged from the electricity grid until the battery is fully charged. at the cheapest tariff. When the battery is fully charged, the supply from grid is deactivated. As long as the battery is full, there are transitions between the scenario 1 and scenario 4 , in which the battery is the main power supply.After the sunrise, transitions were observed between 2 and 6 scenarios for a short time instead of the scenario 4. Transitions between scenarios 3 and 5 were observed from sunrise till to sunset. The difference of the scenarios 3 and 5 from the scenarios 4 and 6 is that it is active in photovoltaic panels are active. The main basis for the passage of scenarios 3 and 5 is that the battery is full and half full. There were transitions between the scenarios 1 and 7 in the evening hours when the energy use was the most intensive and the most expensive. There were also transition between 1 and 7 in the early hours of the night.

In the scenario 7, the full battery is intended to meet the internal requirement.. It is also defined in this scenario that, if there is an excess energy in the battery over the internal need, this excess energy is sold to the grid. This situation continues until midnight.

According to the data obtained in June and when the battery is half full, scenario transitionstatus, voltage variation and scenario alteration graphs of the scenarios for 24 hours are shown in Fig. 16, 17 and 18, respectively. 


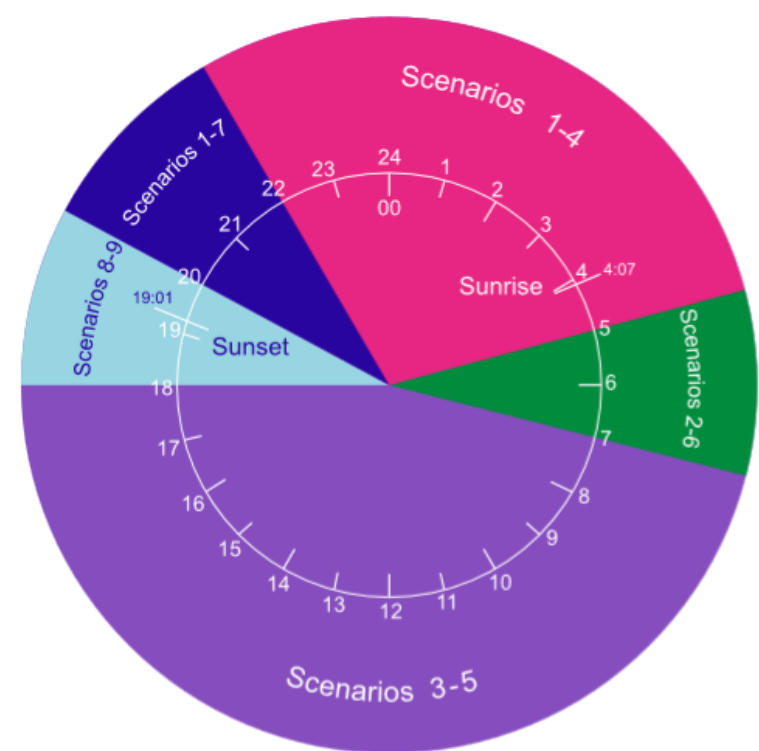

Figure 16. Scenario Transition Status When Battery is Half Full in June

As shown in Fig. 16, the real-time based alteration graph of the scenarios during a whole day, there were transitions between the scenarios 3 and 5 worked transitively during the daytime. The main reason for this transition is to alternate between the half full and full levels of the battery charge rate. When the battery is full, the scenario 5 is active and the battery is also included as a power supply. After a while, the discharged battery reaches its half full level and the scenario 3 becomes active, in which the battery is recharged.

In these two scenarios, as it is daytime, photovoltaic panels are active. With the sunset, the panels lost their effect. In this case, the scenarios 8 and 9 were activated for a short time and then the scenario 1 was activated. With the discharging of the batteries, the transition between the scenario 1 and 4 continued after midnight.

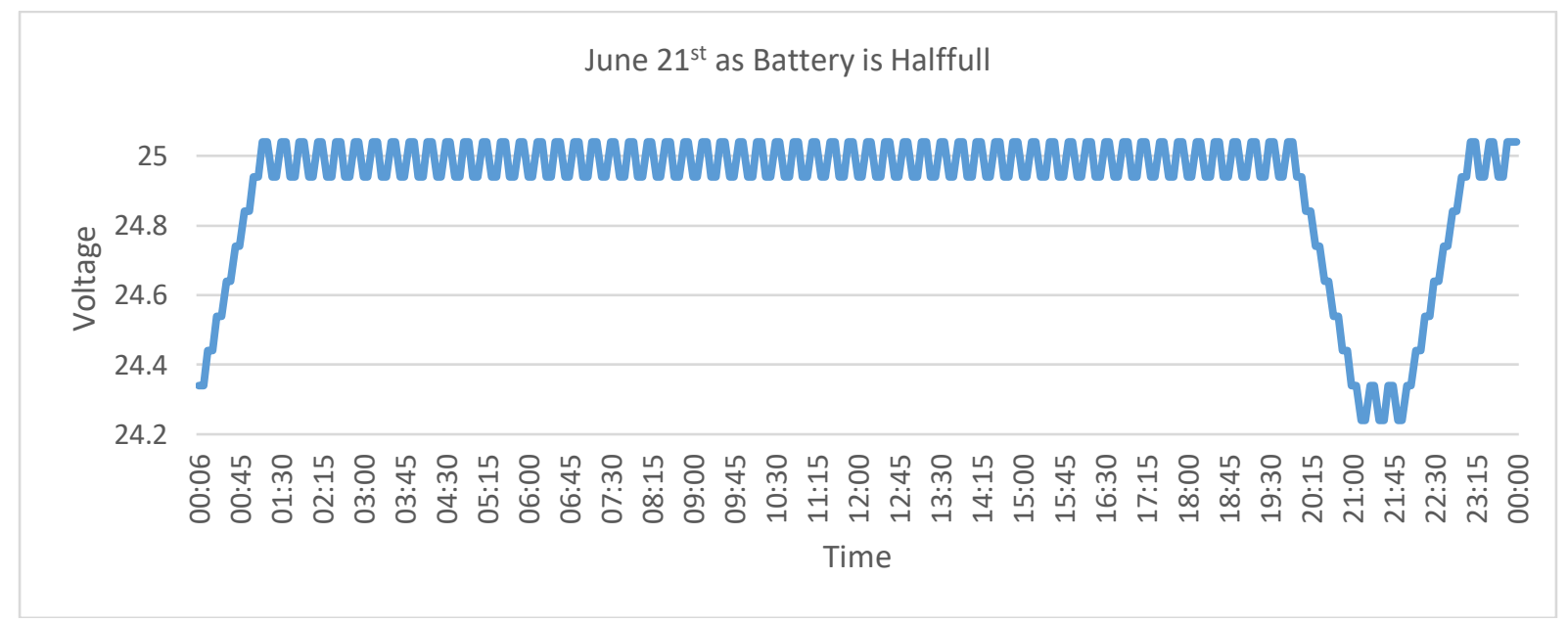

Figure 17. Voltage Change When the Battery is Half Full in June

The battery voltage level change in Fig. 17 confirms the condition in Fig. 16. The battery level is effective at the primary level during scenario alterations. Panel or network preferences have been activated according to day and night conditions. 


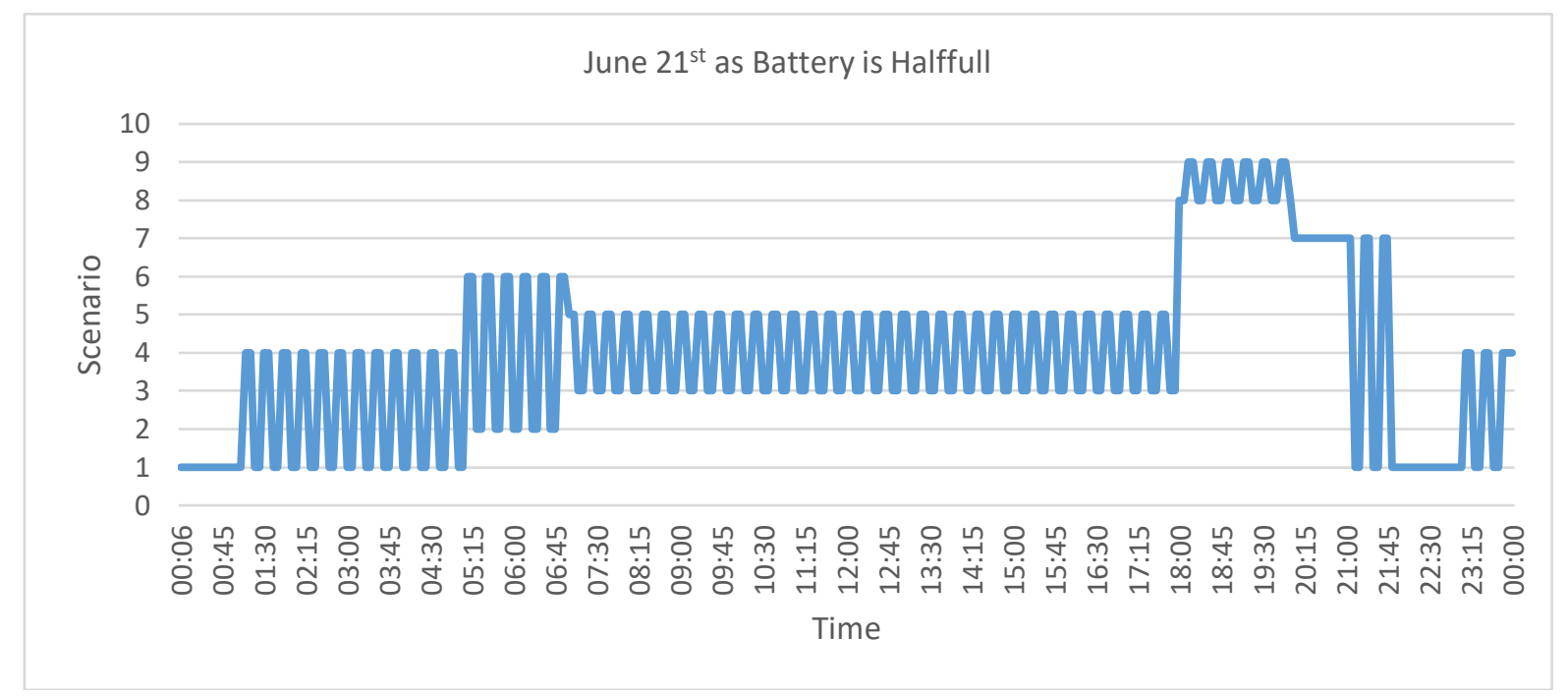

Figure 18. Scenarios when the battery is half full in June

In Fig. 18, transitions between scenarios 1 and 4 and scenarios 3 and 5 are shown. Similarly, in other time intervals, transitions between scenarios 2 to 6 , scenarios 8 and 9 and scenarios 1 and 7 were observed.

In this study, an energy management system has been targeted in which energy needs for green buildings are met from cheap and clean energy sources. In the targeted energy management application, photovoltaic resources are actively used as the main energy source during daytime. In addition, this energy informatics application is based on charging the batteries through the energy source determined on the software. At the evening hours when electricity is more expensive, it is intended primarily to use the energy stored in the batteries until the battery runs out . During the night when the energy is cheap, it is planned that the energy needs will be met and the empty batteries will be charged from the grid. In this context, scenarios 3 and 5 which provide intensive use of photovoltaics were found to be active in the daytime hours. It has been found in the studies that, scenarios 7, 9 and 10, in which the battery-based energy is used, are active in the hours when the energy is expensive. It was observed that scenarios 1 and 4, which are based on the grid, were active at night hours when the energy is affordable. It has been observed that such results are obtained in the simulation studies.

\section{CONCLUSIONS}

In recent years, the fields of application of energy informatics have increased and the use of renewable energy sources and smart grids has become widespread.

In smart grid applications, energy informatics and energy management concepts related to energy informatics have a great importance. In this study, an energy management application based on increasing the use of renewable energy has been realized. Thus, the application area of energy informatics has been contributed.

The scenarios developed in this study are based on providing the use of renewable and affordable energy form in accordance with the green house concept. 
These developed scenarios underlie the energy implementation. These scenarios are based on the basic principle like battery level and utilizing photovoltaic panels. Thus, from sunrise to sunset, it has been ensured that, primarily the PV panels and then the batteries are used as a primary source.

It is possible to increase the number of scenarios and to develop energy management system according to more variable situations by increasing the parameters used in determining the scenarios in this study. The number of scenarios can be increased and the energy management system can be developed by considering the fact of the variability of the charge, the battery capacities and the variation in the amount of energy produced in the panels. The energy management system developed in this study can be evolved and refined inreal time and with more realistic data by adding measurement devices such as smartmeters. In addition, the existing energy system can be improved by including the effects of external factors on the performance of photovoltaic panels such as temperature, partial shading, dust etc.

\section{REFERENCES}

[1] Karaoğlu, B., Üniversiteler Için Fizik [Physics for Universities], Ankara, Turkey, Seçkin Publishing, 2012.

[2] Pamir, N., Enerji Politikalarl ve Küresel Gelişmeler [Energy Policies and Global Developments], Küreselleşmenin Enerji Sektöründe Yapısal Değişim Programı ve Enerji Politikaları [Structural Change in the Energy Sector of Globalization and Energy Policies], 5. Enerji Sempozyumu Bildiriler Kitabı [5th Energy Symposium Proceedings Book], (2005), pp.72-73.

[3] Prevenslik, T.V., Cavitation induced Becquerel effect, Elsevier Science B.V., (2003), pp. 323-327. DOI: 10.1016/S0041-624X(03)00083-0

[4] Würfel, P., Physics of solar cells: from principles to new concepts, Berlin, Germany: Wiley-Vch Verlag GmbH \& Co. KGaA, Weinheim ISBN: 3-527-40428-7, 2005, pp. 198.

[5] Akman, E., Akın, S., Karanfil, G., Sönmezoğlu, S., Organik güneş pilleri [Organic solar cells], Trakya University Journal of Engineering Sciences, 2013, 14(1), 1-30.

[6] Çelebi, G., Bina düşey kabuğunda fotovoltaik panellerin kullanım ilkeleri [Usage principles of photovoltaic panels in building vertical shell], Journal of the Faculty of Engineering and Architecture of Gazi University 2002, 17(3), 17-33.

[7] Kocatürk, A.S., Ünsan, Y., Rüzgâr enerji santrallerinin tarihsel gelişimi ve açik deniz rüzgâr enerji santrallerinin tipleri [Historical development of wind power plants and types of offshore wind power plants], ITÜ Gemi Inşaatı ve Deniz Bilimleri Fakültesi Dergisi [ITU Journal of Faculty of Naval Architecture and Marine Sciences], 2015, 2, 3-16.

[8] Global Wind Statistics, Global Wind Energy Council (GWEC), Brussels, Belgium, 2018.

[9] Erkul, H., Jeotermal enerjinin ekonomik katkıları ve çevresel etkileri [Economic contributions and environmental effects of geothermal energy], Çanakkale Onsekiz Mart Üniversitesi Yönetim Bilimleri Dergisi [Çanakkale Onsekiz Mart University Journal of Management Sciences], 2012, 10(19), 1-30.

[10]Karagöl, E.T., Kavaz, İ., Dünyada ve Türkiye'de yenilenebilir enerji [Renewable energy in the World and Turkey], Seta Foundation Ankara, Turkey, 2017, 197, pp. 17.

[11] Akkaya, U., Gültekin, A.B., Dikmen, Ç.B., Durmuş, G., Baraj ve hidroelektrik santrallerin (HES) çevresel etkilerinin analizi: Ilısu Barajı örneği [Analysis of Environmental Impacts of Dam and Hydroelectric Power Plants (HEPPs): Example of Ilisu Dam], Karabük University $5^{\text {th }}$ International Advanced Technology Symposium, 2009, 2212-2218.

[12]Koç, E., Şenel, M.C., Dünyada ve Türkiye'de enerji durumu - Genel değerlendirme [Energy situation in the World and Turkey - General assessment], Mühendis ve Makina Odası Dergisi [Chamber of Engineers and Machinery Journal], 2003, 54(639), 32-44.

[13]Yakıncı, Z.D., Kök, M., Yenilenebilir enerji ve toplum sağlığı [Renewable energy and community health], Inönü Üniversitesi Sağllk Hizmetleri Meslek Yüksek Okulu Dergisi [İnönü University Journal of Vocational School of Health Services], 2017, Vol. 5(1), 45-58.

[14]Chiras, D.,The Homeowner's Guide To Renewable Energy, New Society Publishers, 2006, pp. 32.

[15] Kavak, K., Dünyada ve Türkiye'de enerji verimliliği ve Türk sanayiinde enerji verimliliğinin incelenmesi [Energy efficiency in the world and Turkey and energy efficiency in Turkish industry], Planlama Uzmanlığ Tezi [Planning Expertise Thesis], Iktisadi Sektörler ve Koordinasyon Genel Merkezi [Economic Sectors and Coordination Headquarters], 2005. ISBN 975-19-3782-5 
[16] Söğüt, Z., Binalarda enerji taraması ve örnek uygulama [Energy screening in buildings and model implementation], Savunma Bilimleri Dergisi [The Journal of Defense Sciences], 2009; 8(2): 143-127.

[17]Watson, R.T., Boudreau, M.C., Energy Informatics, USA. Green e-press, 2011, ${ }^{\text {st }}$ Edition.

[18]Watson, R.T., Boudreau, M.C., Chen, A.J., Information Systems and Environmentally Sustainable Development: Energy Informaticsand New Directions for the IS Community, MIS Quarterly, 2010. 34(1), 2338. DOI: $10.2307 / 20721413$

[19]Brocke, V., Fridgen, G., Hasan, H., Ketter, W., Watson, R.T., Energy Informatics: designing a discipline (and possible lessons for the IS community, (ICIS ) International Conference on Information Systems, 2013, 14351440 .

[20]Akgün, E., Enerji verimliliğinde verimlilik: Enerji yönetimi [Efficiency in energy efficiency: Energy management], TTMD Dergisi [Journal of TTMD], 2017, 108, 38-43.

[21] Watson, R.T., Boudreau, M.C., Energy Informatics, Department of MIS Terry College of Business The University of Georgia Athens, Georgia, USA, 2011.

[22]Şimşek, E.P., Sürdürülebilirlik Bağlamında Yeşil Bina Olma Kriterleri "Kağıthane Ofispark Projesi Örneği [The Criteria for Being Green Building in Context of Sustainability "Kağıthane Ofispark Project as an Example”], Tez (Yüksek Lisans) - İstanbul Teknik Üniversitesi Fen Bilimleri Enstitüsü [Thesis (M.Sc.) İstanbul Technical University, Institute of Science and Technology], İstanbul,Turkey, 2012

[23]Sur, H., Çevre Dostu Yeşil Binalar [Environmentally Friendly Green Buildings], Yeşil Binalar Referans Rehberi [Green Buildings Reference Guide], İstanbul, 2012, pp. 4-5. retriewed from: https://issuu.com/xxi_dergi/docs/yesil_binalar_small

[24]KOERİ-BOUN: Annual sunrise-sunset times for Kahramanmaraş, Retriewed from:http://www.koeri.boun.edu.tr/astronomy/dogus-batis/Kahramanmaras.htm

[25]Enirgi Power Storage, State of Charge Chart, Retriewed from: http://www.enirgipower.com.au/techsupport/battery-maintenance/testing/

[26]Aktaş, F., Hastane Otomasyon Projesi [Hospital Automation Project], Lisans Bitirme Projesi [Undergraduate Dissertation], Dumlupınar Üniversitesi Bilgisayar Bölümü [Dumlupınar University Computer Department], Kütahya,Turkey, 2013.

[27] Ergüzen, A., Ünver, H.M., Özcan, A., Kökver, Y., Aydoğan, E., Kırıkkale Üniversitesi Uzaktan Ĕ̌itim Sistemi Mesajlar Modülü [Kırıkkale University Distance Training System Messages Module], Akademik Bilişim'11 - XIII. Akademik Bilişim Konferansı Bildirileri [Academic Information'11 - XIII. Academic Informatics Conference Presentations], İnönü University, Malatya,Turkey, 2011.

[28]Çimeliler, A., Çelik, N., Bilgi ve Erişim Amaçlı bir Tekstil Web Sitesinin Tasarımı ve Uygulaması [Design of a Textile Web Site for Information and Communication and Its Application], Çukurova Üniversitesi Fen Bilimleri Enstitüsü [Cukurova University Institute of Science and Technology], Adana, Turkey, 2008 19(4). 


\section{APPENDIX 1}

\section{Pseude Code}

The pseudo code created for implementation of the decision making application for the Hybrid Green Building Energy Source Management Software is as follow.

If it is daylight, time is between 06:00-16:59 and the battery is full: scenario 3

If it is daylight, time is between 06:00-16:59 and the battery is half full: scenario 5

If it is daylight, time is between 06:00-16:59 and the battery is empty: scenario 2

If it is daylight, time is between 17:00-21:59 and the battery is full: scenario 9

If it is daylight, time is between 17:00-21:59 and the battery is half full: scenario 8

If it is daylight, time is between 17:00-21:59 and the battery is empty: scenario 2

If it is daylight, time is between 22:00-05:59 and the battery is full: scenario 6

If it is daylight, time is between 22:00-05:59 and the battery is half full: scenario 2

If it is daylight, time is between 22:00-05:59 and the battery is empty: scenario 2

If it is night, time is between 06:00-16:59 and the battery is full: scenario 10

If it is night, time is between 06:00-16:59 and the battery is half full: scenario 1

If it is night, $\quad$ time is between 06:00-16:59 and the battery is empty: scenario 1

If it is night, time is between 17:00-21:59 and the battery is full: scenario 7

If it is night, time is between 17:00-21:59 and the battery is half full: scenario 7

If it is night, time is between 17:00-21:59 and the battery is empty: scenario 1

If it is night, time is between 22:00-05:59 and the battery is full: scenario 4

If it is night, time is between 22:00-05:59 and the battery is half full scenario 1

If it is night, time is between 22:00-05:59 and the battery is empty: scenario 2 